\title{
Judge Robert MacKay's 1882 Catalogue of Books: A Preliminary Analysis
}

\author{
Peter F. McNally and Christina M. Boyle
}

\begin{abstract}
Robert Mackay (1816-1888) was a Judge of the Superior Court from 1868 to 1882, served on the McGill Board of Governors from 1879 to 1887 , and bequeathed his library to the University. The collection comprised two parts: "Legal" and "Miscellaneous." This article discusses the non-legal miscellaneous section, composed of 456 titles in 1,136 volumes, and analyses the collection under subject (10 categories), periodicals (13), country of publication (9), language (8) and period of publication (4). The subject classification is analysed and discussed in further detail.
\end{abstract}

Robert Mackay (1816-1888) a été juge à la Cour supérieure de 1868 à 1882, et a fait partie du Conseil des gouverneurs de McGill de 1879 à 188\%. Il a légué sa bibliothèque à l'Université. La collection se divise en de'ux parties: "juridique" et "divers." Cet article s'intéresse à la partie non juridique de la collection qui se compose de 456 titres en 1,136 volumes et l'analyse en fonction des sujets (10 catégories), des périodiques (19), du lieu de publication (9 pays), de la langue (8) et de la date de la publication (4). La classification par sujet est analysée en détail.

$\mathrm{H}_{\mathrm{is}}$ istorians of McGill University not only outline the administrative course of the University, they also trace its intellectual development: the ideas that shaped the University and the shape that the University gave to ideas. One of the ways of evaluating this intellectual ebb and flow is the library and its collections. These collections constitute a barometer of both the University's impact upon society and society's impact upon the University.

As a recent study indicated, the McGill Library catalogue of 1876, listing 5,201 titles and 11,021 volumes, provides a unique and convincing insight into the collection at that time, and thereby the intellectual state of the University. ${ }^{1}$ By 1882 , the collection had grown to 22,000 volumes, due largely to the gifts of individuals such as Peter Redpath, J.H.R. Molson, and T. Sterry Hunt. Unfortunate as it is that no other book catalogues of the entire collection were issued after 1876 , it is fortunate that catalogues were published thereafter of specific sections of the McGill collection. One such catalogue represents the gifts of Judge Robert Mackay, ${ }^{2}$ most of whose books can still be found on the shelves of the McGill University Libraries.

Robert Mackay was born in Montreal on October 27, 1816 and died there on February 23, 1888. After being admitted to the Bar on December 30, 1838, he developed a highly successful law practise in partnership with W.H. Austin, and received acknowledgement of his professional accomplishments by becoming Batonnier of the Montreal Bar. In 1867, he became Queen's Counsel and in 1868 Judge of the Superior Court. Due to ill helath, he retired from the judiciary on November 1,1882 . He was twice married, first to Ann Kearney of New York, who died in April 1843, and second on June 27, 1848 to Christina - daughter of the Honorable Thomas Mackay of Ot- 


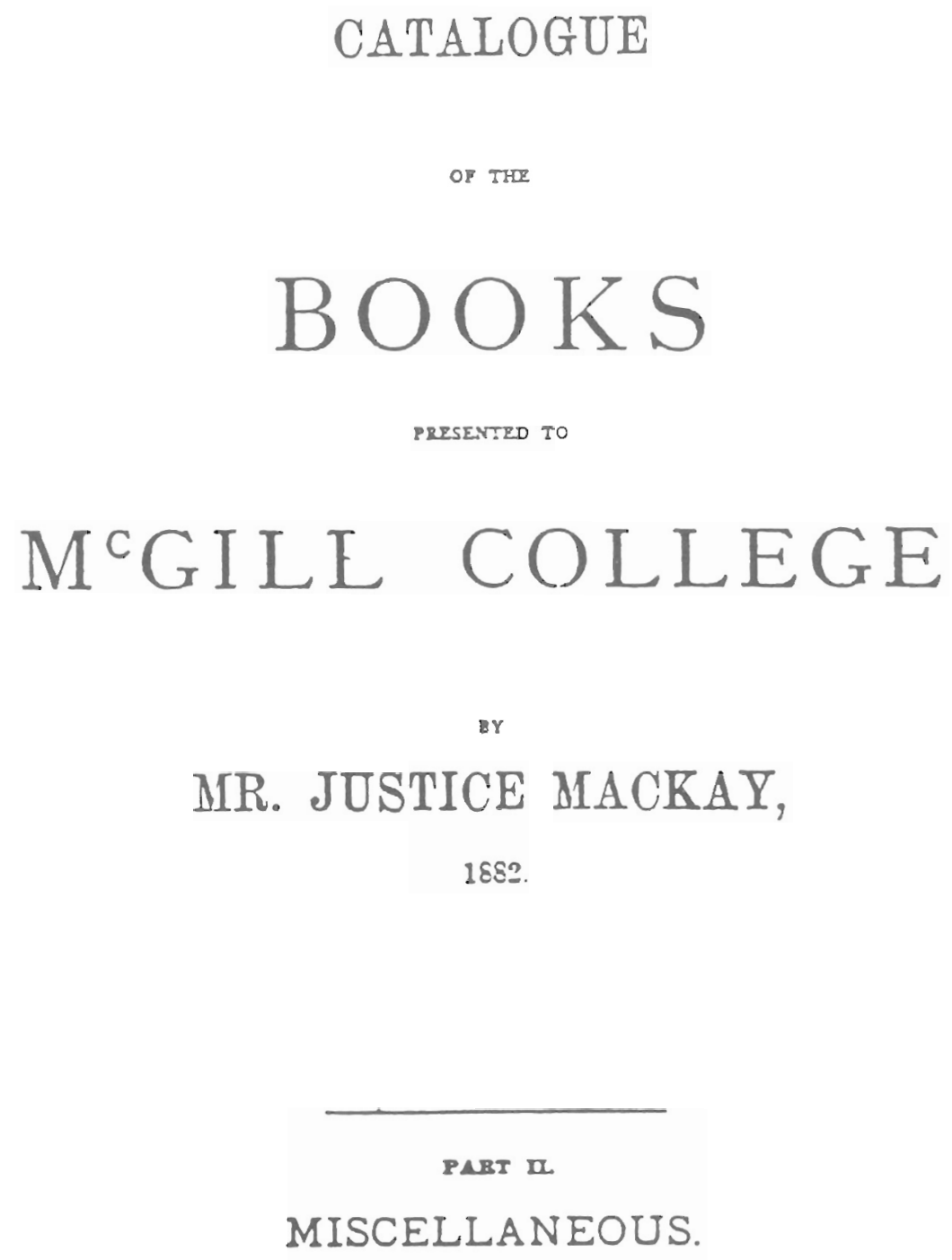

Yoci-ind:

PRLITED BJ JOEY LOVELL \& SOY, ST. NICEOLAS STREET. 1882. 
tawa, the builder of Rideau Hall - by whom he had a daughter. In addition to his legal/judicial career he had a great interest in art, becoming President of the Montreal Art Association in 1882. He was also a philanthropist, giving some of his art collection to the Fraser Library and donating money to the Diocesan Theological College. Most importantly for our story, he served on the McGill Board of Governors from 1879 until his resignation in December 1887, shortly before his death, and gave the University his library. ${ }^{3}$

Described in a catalogue published in $1882 / 1883$, Mackay's collection can be evaluated for both its quantity and quality, and for its interaction with the intellectual development of the University. Composed of approximately 2,000 titles, his collection would have constituted approximately $10 \%$ of the University Library book stock of the early $1880 \mathrm{~s}^{4}$ The collection is divided into two parts: Part I "Legal" and Part II "Miscellaneous," or non-legal publications. Interestingly enough, the imprint date of the title page for Part II is 1882, whereas that for Part I is 1883. It is unclear whether the two parts were issued separately or as one title. Since the analysis of Part I is still in progress, this paper will deal only with Part II, the non-legal "Miscellaneous" publications.

Part II is composed of 456 titles in 1,136 volumes. The total number of volumes may actually be larger, but bibliographical ambiguities make it difficult to identify certain titles: the entries are exceedingly brief, typically one line in length, with abbreviated author and title and rarely a date of publication, but usually an indication of number of volumes. Handwritten lists in the McGill Archives suggest that the books were received before being catalogued. ${ }^{5}$ Although there is no indication of who catalogued them, one can speculate that it was M. William Taylor, the Assistant Librarian. As the catalogue's titlepage makes clear, the arrangement was by subject, there being ten categories as follows:

Several points require clarification. Section E, "Parliamentary and Political," includes 90 volumes of British Parliamentary debates and histories, now located in the McLennan Library's Government Dockment Department. Section F, "The Works Of," handles the collected works of such authors as Voltaire (71 vol.), Burke (2 vol.) and Rabelais (1 vol.). Section H, "Classical Library," is a series of ciassical

\begin{tabular}{lcccc}
\multicolumn{5}{c}{ Table 1: } \\
\hline \hline $\begin{array}{l}\text { NUBJECT } \\
\text { TITLES }\end{array}$ & $\begin{array}{c}\text { NO. OF } \\
\text { VOLS. }\end{array}$ \\
\hline A. DICTIONARIES & 18 & 3.9 & 50 & 4.4 \\
B. HISTORY & 45 & 9.9 & 165 & 14.5 \\
C. BIOGRAPHY & 29 & 6.4 & 68 & 6.0 \\
D. POETRY & 20 & 4.4 & 63 & 5.5 \\
E. PARLIAMENTARY & 14 & 3.3 & 145 & 12.8 \\
$\quad$ \& POLITICAL & & & & \\
F. THE WORKS OF & 11 & 2.4 & 95 & 8.4 \\
G. RELIGIOUS & 41 & 9.0 & 54 & 4.8 \\
$\quad$ \& CONTROVERSIAL & & & & \\
H. CLASSICAL LIBRARY & 19 & 4.2 & $50 ?$ & 4.6 \\
I. HARPER'S FAMILY & 126 & 27.6 & 187 & 16.5 \\
$\quad$ LIBRARY & & & & \\
J. OTHER BOOKS & 132 & 28.9 & $257+$ & 22.6 \\
TOTAL & $456+$ & 100 & $1136+$ & 100.1 \\
\hline \hline
\end{tabular}

Table 2:

The Anti-Jacobin Review, 1798-1810, 36 vol.

The Illustrated London News, 1858-1871, 14 vol.

The Eclectic Magazine (Boston), 6 vol.

The Leisure Hour, 1854-1860, 1862-, 16 vol.

Good Words, 1860-, 12 vol.

The Penny Magazine, 1832-1845, 13 vol.

The Saturday Magazine (London), 1832-1844, 13 vol.

Bell's Weekly Messenger, 1814-1815, 2 vol.

Colonial Magazine, 3 vol.

Revue canadienne, 2 vol.

The Argosy, 2 vol.

The Art Union, 2 vol.

The Art Journal, 3 vol.

authors in English translation. Section I, "Harper's Family Library," is a miscellaneous series composed largely of non-fiction. Section J, "Other Books," is a richly textured group of books and periodicals, covering virtually every subject discipline. The collection contains thirteen periodical titles in approximately 124 volumes:

Whereas British publications predominated in the 1876 McGill Library catalogue, American publications predominated in Mackay's:

Of the American publications 155 , or $85.6 \%$ of their total, were published in New York City. Of the British, 139 or $86.8 \%$ were published in London, and only 13 or $8.1 \%$ were published in Scotland. Of the Canadian publications, 12 or $70.6 \%$ were published in Montreal. Analysis of the "Legal" Part of the catalogue will undoubtedly show a much higher pro- 
Table 3:

\begin{tabular}{lcc}
\hline \hline COUNTRY & $\begin{array}{c}\text { NUMBER OF } \\
\text { TITLES }\end{array}$ & $\%$ \\
\hline United States & 181 & 39.7 \\
United Kingdom & 160 & 35.1 \\
Canada & 17 & 3.7 \\
France & 13 & 2.9 \\
Belgium & 3 & 0.7 \\
Holland & 3 & 0.7 \\
Switzerland & 2 & 0.4 \\
Italy & 2 & 0.4 \\
Unknown & 75 & 16.4 \\
TOTAL & 456 & 100 \\
\hline \hline
\end{tabular}

Table 4:

\begin{tabular}{lcc}
\hline \hline LANGUAGE & NO. OF & $\%$ \\
& TITLES & \\
\hline ENGLISH & 409 & 89.7 \\
FRENCH & 30 & 6.6 \\
LATIN & 7 & 1.5 \\
ITALIAN & 3 & 0.7 \\
FRENCH \& ENGLISH & 3 & 0.7 \\
GREEK \& ENGLISH & 1 & 0.2 \\
POLYGLOT: LATIN, ITALIAN & 1 & 0.2 \\
$\quad$ DUTCH \& FRENCH & & \\
UNKNOWN & 1 & 0.2 \\
TOTAL & 456 & 166 \\
\hline
\end{tabular}

portion of Canadian imprints, which otherwise were significantly fewer than in the 1876 catalogue.

English was overwhelmingly predominant as the language of publication. Although the Latin language fell only from second place in the 1876 catalogue to third in Mackay, its proportion of the total was dramatically less. As for the titles in French, the number given here may be lower than is really the case, due to the tendency to translate titles into English. Some of these translations may have been missed in the analysis.

Although the date of publication of 80 titles, or $17.5 \%$ of the total, was indeterminable, the focus of those with dates was overwhelmingly upon the nineteenth-century:

The 1840 s, with 188 titles or $50 \%$ of the indentifiable total, provided the largest number of publications, and this suggests that Mackay did the bulk of his purchasing in this period. Virtually all of 126 titles in the "Harper's Family Library" series were pub-
Table 5:

\begin{tabular}{lcc}
\hline DATE & NO. OF TITLES & $\%$ \\
\hline $1551-1599$ & 3 & 0.8 \\
$1600-1699$ & 5 & 1.3 \\
$1700-1799$ & 23 & 6.1 \\
$1800-1880$ s & 345 & 91.8 \\
TOTAL & 376 & 100 \\
\hline \hline
\end{tabular}

Table 6:

\begin{tabular}{lcc}
\hline \hline SUBJECT & $\%$ & $\begin{array}{c}\text { No. OF } \\
\text { TITLES }\end{array}$ \\
\hline OTHER BOOKS & 28.9 & 132 \\
HARPER'S FAMILY & 27.6 & 126 \\
$\quad$ LIBRARY & & \\
HISTORY & 9.9 & 45 \\
RELIGIOUS & 9.0 & 41 \\
$\quad$ \& CONTROVERSIAL & & \\
BIOGRAPHY & 6.4 & 29 \\
POETRY & 4.4 & 20 \\
CLASSICAL LIBRARY & 4.2 & 19 \\
DICTIONARIES & 3.9 & 18 \\
PARLIAMENTARY & 3.3 & 15 \\
$\quad$ \& POLITICAL & & \\
THE WORKS OF & 2.4 & 11 \\
\hline \hline
\end{tabular}

lished in that decade. By comparison, all 19 titles in the "Classical Library" were published in the 1830s.

Subject analysis was undertaken first by reorganizing Table One in descending order by percentage of titles. As Table Six shows, "Harper's Family Library" and "Other Books" accounted for 56.5\% of the titles. Further subject analysis was clearly required to deal with this subject indeterminancy.

The Mackay entries were then checked in the McGill Library catalogues, where a high proportion were found with either Library of Congress or Cutter Classification numbers. The Cutter system was used at McGill until 1967 and is still in use for some older materials, whereas others have been reclassified into L.C. As much as possible, the classification numbers are presented as given in the catalogues, the exceptions being L.C.'s AC and Cutter's Y9, which are so general that it was deemed acceptable to reassign their titles to more appropriate categories. As two classification systems were being analyzed, they were blended as follows: 
Table 7:

\begin{tabular}{|c|c|c|}
\hline SUBJECT CLASSIFICATION & $\begin{array}{l}\text { NO. OF } \\
\text { TITLES }\end{array}$ & $\%$ \\
\hline $\begin{array}{l}\text { 1. DICTIONARIES, \& } \\
\text { ENCYCLOPEDIAS }\end{array}$ & 19 & 42 \\
\hline $\begin{array}{l}\text { 2. GENRAL WORKS } \\
\text { INCLUDING PERIODICALS }\end{array}$ & 12 & ¿.6 \\
\hline $\begin{array}{l}\text { 3. PHILOSOPHY, PSYCHOLOGY, } \\
\& \text { OCCULT }\end{array}$ & 19 & 4.2 \\
\hline 4. RELIGION & 56 & 12.3 \\
\hline 5. HISTORY, ALLIED & 6 & 1.3 \\
\hline 6. BIOGRAPHY & 41 & 9.0 \\
\hline 7. HISTORY & 114 & 25.0 \\
\hline $\begin{array}{l}\text { 8. GEOGRAPHY, TRAVEL } \\
\text { ANTHROPOLOGY, } \\
\text { \& RECREATION }\end{array}$ & 10 & 3.3 \\
\hline 9. SOCIAL SCIENCES & 9 & 2.0 \\
\hline 10. POLITICAL SCIENCE & 16 & 3.5 \\
\hline 11. LAW & 4 & 0.9 \\
\hline 12. EDUCATION & 3 & 0.7 \\
\hline 13. FINE ARTS \& ARCHITECTURE & 15 & 3.3 \\
\hline $\begin{array}{l}\text { 14. LANGUAGE } \\
\text { \& LITERATURE (GENERAL) }\end{array}$ & 4 & 0.9 \\
\hline 15. CLASSICAL L \& L & 22 & 4.8 \\
\hline 16. ENGLISH L \& L & 60 & 13.2 \\
\hline 17. ROMANCE L \& L & 7 & 1.5 \\
\hline $\begin{array}{l}\text { 18. SCIENCE, MEDICINE, \& } \\
\text { AGRICULTURE }\end{array}$ & 33 & 7.2 \\
\hline 19. UNKNOWN & 1 & 0.2 \\
\hline TOTAL & 456 & 100.1 \\
\hline
\end{tabular}

The results provide an invaluable insight to the collection. In Table Six, "History" and "Biography" account for $16.3 \%$ of the total, whereas in Table Seven sections 6 and 7 account for $34 \%$, and when taken with "Geography," section 8, for $37.3 \%$. In Table Six, "Dictionaries," "Poetry," "The Works Of," and "Classical Library" account for $14.9 \%$, but in Table Seven, sections 1, 13-17 dealing with language and literature account for $24.6 \%$. "Religious \& Controversial" rises from $9.0 \%$ in Table Six to $12.3 \%$ in section 4 of Table Seven. "Political" remains quite stable at $3.3 \%$ in Table Six and $3.5 \%$ in Table Seven. The appearance in Table Seven of section 18, "Science, Medicine, \& Agriculture," was an unexpected surprise. Overall, the subject analysis of Table Seven enhances the appreciation of the Mackay collection and shows that history, biography, language and literature were its focal point.

In evaluating this collection, it is easier to provide questions than answers. The first question is whether Mackay's books were acquired primarily for his own reading or, in the tradition of Peter Redpath, ${ }^{6}$ primarily for use in the McGill Library. Series such as the "Harper's Family Library" suggest personal reading, but the British Parliamentary histories and debates suggest an institutional Cestination. At least to some extent, Mackay may have been deliberately complementing the British history collection of Redpath, a fellow Board member. The next question is whether Mackay's books added to the quality of the McGill collection. To this, the answer is unequivocally yes, particularly given the small size of the University collection in 1882. Even if, by late twentieth-century standards of many of his books are now dated, at the time they would have been timely. At the very least, they are still of continuing historiographical importance, in charting the evolution of particular disciplines and topics. It should also be noted that the twenty-nine volumes of Canadian pamphlets, 1770-1854, listed in B, "History," helped form the nucleus of McGill's famous collection of rare Canadiana. That said, the emphasis upon history in the Redpath and Mackay collections seems extraordinary, given that McGill began teaching it only in the $1890 \mathrm{~s}$. Were these two men so visionary as to have realized that history would soon be taught and such collections would be needed? Or were they simply possessed of such a strong belief in history that, whether it was taught or not, they thought that the young college needed books on the subject? A final point is the phrase "Religious \& 
Controversial" in Table Six, which suggests a critical attitude towards religion that is reinforced by Mackay's funeral having been private and therefore possibly non-religious.

Finally, this evaluation must conclude with an admission that the "Miscellaneous" Part is the smaller portion of a collection, whose larger portion is the "Legal" Part, the analysis of which is required for the full significance of the Mackay books to become clear. In the meantime, one can only applaud the generosity of spirit that prompted Judge Robert Mackay to give such a fine collection to McGill's Library.

\section{Notes}

1. Peter F. McNally and Kevin Gunn, "The McGill University Library Catalogue of 1876: a Preliminary Statistical Analysis." Fontanus, from the Collections of McGill University, v. 9 (1996) pp. 120-124.

2. Catalogue of Books, by Subjects, of the Books Presented to McGill College. by Mr. Justice Mackay, 1882. Montreal, Lovell, 1882-1882. 2 parts [Part I, Legal, 1883, 26 p; Part II, Miscellaneous, 1882,16 p.].

3. Montreal Gazette, February 24, 1888, p. 4, February 25, p. 3, February 27, p. 2, February 28, p. 3, March 1, p. 3. Montreal Herald, February 24, 1888, p. 5, February 25, p. 8, February 27, p. 8, Henry J. Morgan, Canadian Legal Directory: a Guide to the Bench and Bar of the Dominion of Canada. Ioronto, Carswell, 1878. p. 234. Quebec Law Reports. v. III, no. II (November, 1882), List of Subscribers, P.-G. Roy, Les Juges de la Province de Québec. Québec, Sa Majesté, 1933. pp. 330-331. Brian Young, The Politics of Codification: the Lower Canadian Civil Code of 1866. Montreal, McGillQueen's, 1994. pp. 110, 214. There is some variation among the sources concerning the courts in which Mackay server as a judge, and his role in the development of the Quebec civil code.

4. McGill University Archives. Record Group 40, Jontainer 2, File "Principal Donors to the Library, 1882-1885-Lists".

5. -File "Mackay Library".

6. See P.F. McNally's forthcoming article on Peter and Grace Redpath. 